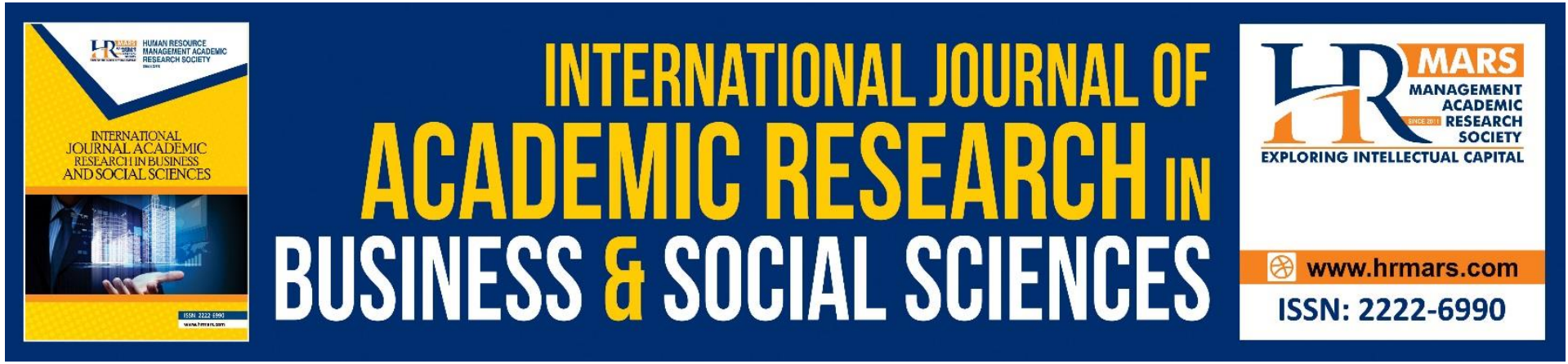

\title{
Predictors and Moderator of Telework Adjustment among Labour Union Members During Covid-19 Pandemic: A Conceptual Paper
}

Azizan H Morshidi, Kee Y. Sabariah Kee Mohd Yussof, Jalihah Md. Shah

To Link this Article: http://dx.doi.org/10.6007/IJARBSS/v11-i8/10723

DOI:10.6007/IJARBSS/v11-i8/10723

Received: 09 June 2021, Revised: 13 July 2021, Accepted: 29 July 2021

Published Online: 10 August 2021

In-Text Citation: (Morshidi et al., 2021)

To Cite this Article: Morshidi, A. H., Yussof, K. Y. S. K. M., \& Shah, J. M. (2021). Predictors and Moderator of Telework Adjustment among Labour Union Members During Covid-19 Pandemic: A Conceptual Paper. International Journal of Academic Research in Business and Social Sciences, 11(8), 217-226.

Copyright: @ 2021 The Author(s)

Published by Human Resource Management Academic Research Society (www.hrmars.com)

This article is published under the Creative Commons Attribution (CC BY 4.0) license. Anyone may reproduce, distribute, translate and create derivative works of this article (for both commercial and non-commercial purposes), subject to full attribution to the original publication and authors. The full terms of this license may be seen at: http://creativecommons.org/licences/by/4.0/legalcode

Vol. 11, No. 8, 2021, Pg. 217 - 226

http://hrmars.com/index.php/pages/detail/IJARBSS

JOURNAL HOMEPAGE

Full Terms \& Conditions of access and use can be found at http://hrmars.com/index.php/pages/detail/publication-ethics 


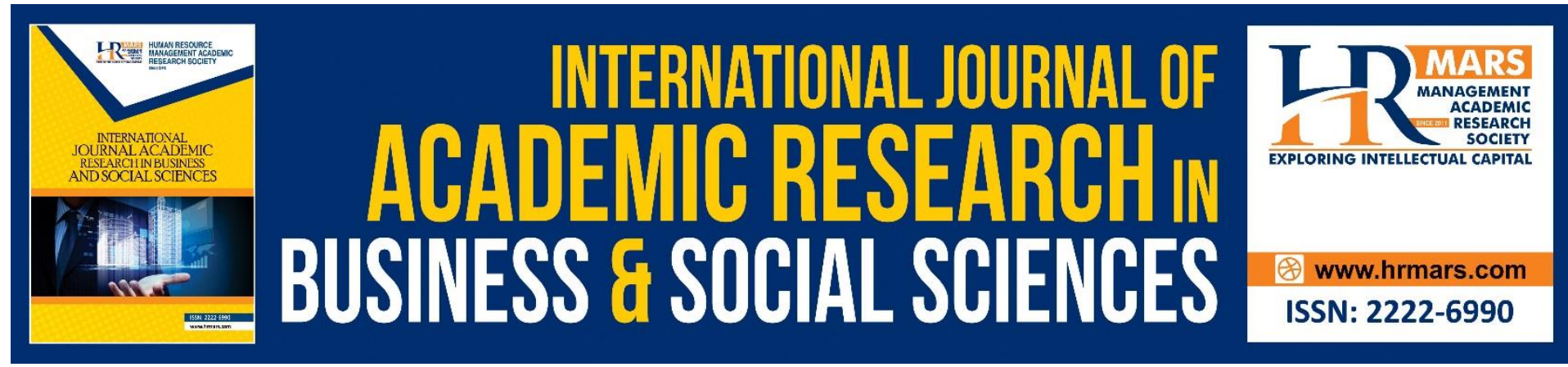

\title{
Predictors and Moderator of Telework Adjustment among Labour Union Members During Covid-19 Pandemic: A Conceptual Paper
}

\author{
Azizan H Morshidi, Kee Y. Sabariah Kee Mohd Yussof, Jalihah \\ Md. Shah
}

Faculty of Social Sciences \& Humanities, Universiti Malaysia Sabah, Malaysia

\begin{abstract}
The pandemic catastrophe caused by covid-19 poses unprecedented problems and has farreaching ramifications for how people working life. Digital technologies have been critical in preserving corporate continuity since lockdown tactics drove employees worldwide to telework, frequently leaving them ill-equipped and unprepared. Thus, labour union members as active employees have been forced to adapt to changing work conditions and practices, as articulated in the Theory of Work Adjustment (TWA). This article suggests that gender may be used to moderate the impacts of trade union support and professional isolation on labour union members' telework adjustment during the COVID-19 pandemic. This conceptual paper posits that telework adjustment may be researched by utilising a local union sample. Additionally, this article serves as a conceptual framework for future study by drawing on theoretical and empirical findings from essential works in adjacent domains.
\end{abstract}

Keyword: Telework Adjustment, Union, COVID-19, Professional Isolation, Gender

\section{Introduction}

COVID-19's pandemic disaster offers significant health and socio-economic concerns and has far-reaching implications on how people live and work across the world. Throughout this volatile time, digital technologies have been crucial in maintaining social relationships between family units and communities and guaranteeing organisational continuity (Fana, et. al., 2020). From the employee viewpoint, governments' introduction of lockdown measures coupled with an abrupt and sudden move to teleworking frequently putting workers not ready and vulnerable to cope with sensitive family/home situations. Employees have been compelled to respond and adjust to changing work environments and practices, as defined in the TWA (Dawis, et. al., 2000). Prior to the covid-19 pandemic crisis, an organization's capacity to sustain business operations and guarantee business continuity was highly dependent on its workers' capacity to migrate from conventional to more virtual work modes successfully. Adjustment to changing work environments entails adjusting to new environmental demands due to changes in the work is organised and the nature of human relationships. By June 2021, despite hints of progress, and given the gradual easing of lockdown limits in some countries, teleworking is a still daily reality for the most of the workers, as authorities have advocated 
businesses to continue remote-working wherever practicable and for an indefinite duration (Carillo, et. al., 2020). There is no doubt that the COVID-19 pandemic has left an indelible mark that altered how employees work, reshaped employer-employee relationships, and reaffirmed the crucial importance of information and communication technologies in work practices. The reshaped employee-employer relationship has created a significant avenue for a labour union to play a significant role in the work design aspect, particularly the telework adjustment. In this pandemic environment, finding and understanding what factors influence union members' ability to "adapt" would aid in the establishment of telework solutions (Agba, et. al., 2021). The effective, practical, and empathetic solutions, not just during the current COVID-19 pandemic and the post-lockdown phase, it may also benefit in the event of a new epidemic possibility (Belzunegui-Eraso and Erro-Garcés, 2020; Wang, et al., 2020). By drawing on the TWA, this paper takes an individual adjustment viewpoint on labour union members (Dawis \& Lofquist, 1984). The research identified an apparent theoretical gap in the prior research concerning telework adjustment. The theory on telework adjustment is relatively new, and the current studies bear the fruit of this theoretical gap. The TWA has received less attention in the labour union sphere, notably (Allen, et. al., 2021; Chang, et. al., 2021; Carillo, et. al., 2020). This theoretical gap provides an opportunity for future exploration by attempting to address the following research question: What factors affect labour union members' telework adjustment during the COVID-19 pandemic?

Furthermore, previous theoretical models need to embrace contemporary research in telework adjustment among labour union members during the pandemic to provide a more robust theoretical basis for studies. Also, based on the review of the prior studies, there is a population gap. Some of this sub-population has been under-researched. The telework adjustment appears to be essential and worthy of investigation in the context of labour union members during the COVID-19 pandemic (Benavides, et. al., 2021; Buomprisco, et. al., 2021; Sládek and Sigmund, 2021). Hence, in this paper, the terms employee and labour union members will be used interchangeably. Telework adjustment during COVID-19 has become a concern because of its operational nature. Rodinova, et. al (2021) iterate that in comparison to telework conducted in a typical setting pre-COVID-19, telework triggered by an epidemic possesses intrinsic characteristics. Telework's purported flexibility of location and working hours is no longer permitted in the COVID-19 environment. Home confinement is enforced, teleworking is made compulsory on a full-time basis, and teleworkers frequently face aggravated professional and personal time management concerns (Raghuram, et.al., 2019). Telework generated by a crisis has unique work environment characteristics due to its execution and the crisis setting in which teleworkers operate (Carillo, et. al., 2020). Work adjustment has a lengthy history in the realm of human resource management. Raghuram et al (2001) conceptualised and operationalised virtual work adjustment in the shift from conventional to virtual ways of work. They evaluated this idea by looking at crucial employee adaptability indicators to new work shifts, and they see adaptation to virtual labour as an encompassing criterion of flexibility that most accurately represents people's ability to respond to external stressors. They advocate for conducting telework adjustment research with data from multiple groups, which may include labour union members and in compulsory telework settings that is more relevant for telework adjustment, as experienced during the COVID-19 pandemic in a developing country such as Malaysia (Azizan, et. al., 2021; Ma, et. al., 2019). 


\section{Literature and Hypothesis Development Telework Adjustment}

This study takes a work adjustment approach to examine how workers respond to the changes in the working environment caused by the events in the Covid-19 pandemic that have compelled them to work virtually. Following TWA, the lockdown and following telework surge look like a radical change in the working environment that has changed the interaction between the employee and the environment, leading people to adapt to this challenging scenario. The concepts presented below have conceptual roots in the TWA (Dawis \& Lofquist, 1984) and respond to the Corillo et al. (2020), focussing on the organisational and job variables and individual variables affecting subsequent telework adjustment. More specifically, the researchers define mandatory telework adjustment in the course of the COVID 19 pandemic in line with Raghuram et al. (2001) to be the level of adaption of employees to new environmental demands in the emerging setting of a worldwide epidemic crisis (Corillo, et. al., 2020; Caranto, et. al., 2020; Lott, et. al., 2020).

\section{Perceived Labour Union Support}

Even though labour unions do not provide direct technical or operational support in teleworking during the pandemic, the unions have the bargaining power to demand a more humane teleworking arrangement. Also, labour unions can demand special Internet datarelated allowances, continuous training, and technical support from their employers. External efforts in the form of perceived labour union support for change might serve the same function in addition to internal attempts to manage a new situation. In the context of our study, perceived labour union aid for change is defined as perceived facilitation by the union to facilitate the adaptation of the labour union members to new teleworking-related changes. Changing to a new method of working with a new system calls for direction and appropriate learning resources. Enabling change through mechanisms like training and the provision of resources might impact union members' response to new changes in digital technology. With increased support for change for the perceived work union, users might respond less adversely and generate less opposition towards installing a new teleworking system (Ma, et. al., 2019; Berg, et. al., 2014).

Just as technology management assistance enhances the simplicity of the technology's use, perceived support from the labour union for changes in training and resources might minimise the perceived difficulty of adjusting to the pandemic-induced teleworking arrangement. More excellent organisational support for change might lessen the time and effort that members need to transition to learn the new functioning method. Therefore, union support for change might indirectly reduce customer resistance by reducing the impression of the switching costs, separate from its direct influence (Chang, et. al., 2021).

\section{Professional Isolation}

Professional isolation is a mental condition or an idea that someone is out of touch at work (Kim, et. al., 2021; Bérastégui, 2021; Bilotta, et. al., 2021). The fundamental effort and need to feel connected to society at work has been suppressed. Although not all teleworking workers report being professionally isolated, research may show that they frequently lack "social barometers" with which to relate themselves to others. (Thomas, et. al., 2021; Beauregard, et. al., 2019; Raghuram, et. al., 2019; Golden, et. al., 2008). Because of these attitudes, professional teleworking employees might have less trust in their talents and 
knowledge and have a discrete drawback in their work. For instance, interpersonal ties and interactions with people might be less efficiently managed in order to coordinate complex, puzzling activities and increase understanding via sharing and improving tacit knowledge. Based on the same rationale, the situation during the pandemic may or may not be worse.

During the COVID-19 epidemic, telecommuting staff may risk experiencing professional isolation. They must preserve their organisational links, and labour unions can play a vital part in achieving this goal. It might be essential to develop and sustain organisational connectivity in a telecommunications environment, as informal interaction between supervisors and staff is less common. One of the most commonly expressed concerns for teleworkers is that their rare presence in the company might render them "out of sight, out of sight," thereby impeding their progress in their careers (Raghuram, et. al., 2001). Such professional isolation might hinder prospects for virtual employees to participate in and benefit from organisational membership. Corporate connectivity might depend on the communication and socialising behaviour of individual virtual workers. Some may be better than others to retain touch with interaction partners through media like telephones or emails or by attempts to create connections when they encounter face-to-face interaction partners. Teleworkers with poor organisational connectedness may lack insight into desirable actions necessary to achieve immediate performance or career possibilities. However, suppose they have good organisational connectedness. In that case, they are likely to be vital to and associated with the company that can encourage corporate commitment and alleviates their career development worries (Wang, et. al., 2020; Golden, et. al., 2008; Raghuram, et. al., 2001).

\section{Gender as a Moderator}

By enabling people to work from home, teleworking intrinsically impacts the link between work and non-working jobs, making it more straightforward for one position to overlap with another. Men and women can play these roles relatively differently and hence have various demands in a virtual environment that may lead them to respond differently to employees' telework adjustment variable (Agba, et. al., 2021; Agba, et. al., 2020). In particular, women might respond more positively to variables that define the field of work explicitly by giving women more significant influence over the work to balance the strain of their non-work commitments. On the other hand, men may consider themselves to be working from a nontraditional place. When a result, males might respond more favourably to characteristics that allow organisational participation to be maintained even as they leave their homes (Abed, 2021; Biron, et. al., 2020; Crooks, et. al., 2020; Zhang, et. al., 2020). Under this rationale, researchers predict women's telework adjustment to be impacted more strongly by characteristics like stated performance requirements and more autonomous activities that make personal control easier and clearly define the boundaries of the work role (Lott and Abendroth, 2020). In other words, men's teleworking adjustment might be impacted more strongly by the interpersonal confidence and connectivity that allow the company to have a strong bond even when they are not physically there (Khan and Umer, 2021; Carillo, et al., 2020; Raghuram, et. al., 2019).

\section{Research Hypothesis}

Subsequently, this research attempts to employ the TWA to understand better telework adjustment among labour union members during the COVID-19 pandemic. Accordingly, this research aims to suggest that gender may be used to moderate the impacts of perceived 
labour union support and professional isolation on labour union members' telework adjustment during the COVID-19 pandemic. Therefore, based on the above preceding discussion, the following research hypotheses will be addressed such as:

$\mathrm{H} 1$ : There is a relationship between professional isolation and telework adjustment among labour union members during the COVID-19 pandemic.

$\mathrm{H} 2$ : There is a relationship between perceived labour union support and telework adjustment among labour union members during the COVID-19 pandemic.

H3: Gender moderates the relationship between professional isolation and telework adjustment among labour union members during the COVID-19 pandemic.

H4: Gender moderates the relationship between perceived labour union support and telework adjustment among labour union members during the COVID-19 pandemic.

\section{Proposed Conceptual Framework}

This paper proposed a conceptual framework to analyse the relationships between gender, professional isolation and perceived labour union support with telework adjustment among labour union members during the COVID-19 pandemic (Figure 1)

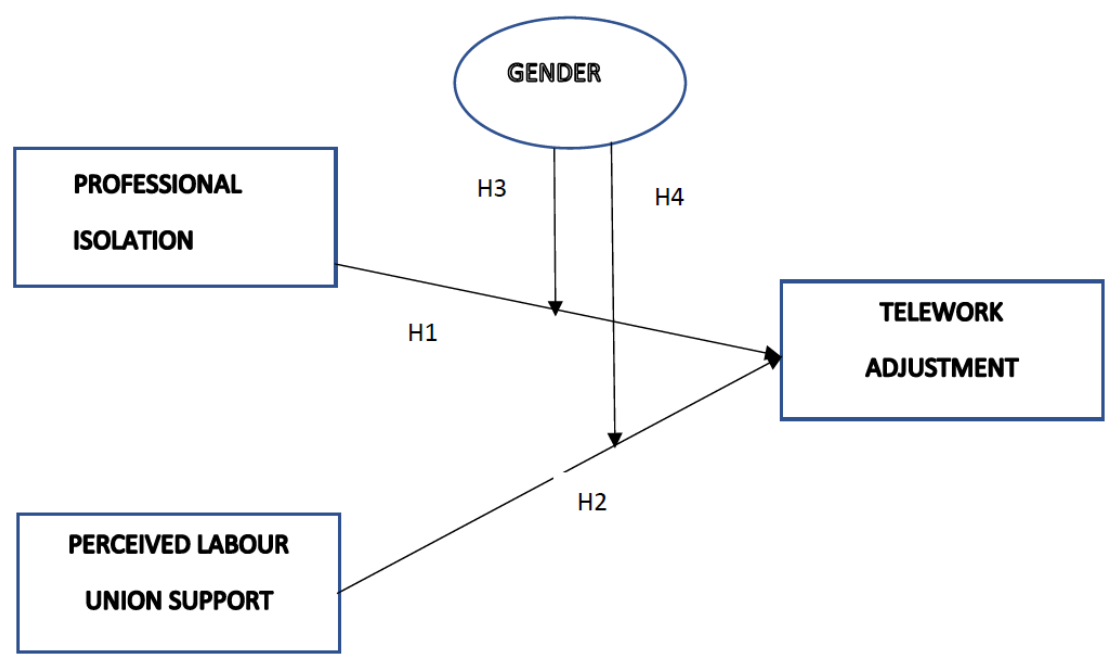

Figure 1: Conceptual framework with factors that influence Telework Adjustment

The proposed conceptual framework will aid scholars, practitioners, unions, and organisations in better understanding the telework adjustment and the role of gender in this mechanism so that all parties involved can contribute to society by creating a productive and conducive telework environment. The findings of this study will theoretically enhance the TWA with the inclusion of union-related variables. Also, the findings will enable a better understanding which telework adjustment in various settings and situations. Additionally, We sincerely hope this paper will help organisations better deal with the current situation and prepare them for dealing with the potential future pandemic.

\section{Proposed Research Methodology}

The current research will engage a pluralist perspective of industrial relations. In parallel with the pandemic setting, all parties must play an active role, and within this very perspective, 
labour unions play an active role in employee-employer relations. The research will employ a quantitative research design with a systematic sampling technique. The survey design will further enable a comprehensive assessment of the elements determining the best possible adjustment by union members to a rapid change of telework in an pandemic. The survey instrument will be adapted from previous studies, and the research instrument will be in the Malay language to accommodate the local Malaysian respondents. The research questionnaire scale will be designed, developed, pretested, and validated based on Rasch Model prior to data collection. The research will ensure the result quality and the inferences made by focusing to the data convergent validity and discriminant validity. The data analysis plan will utilise descriptive statistics and Structural Equation Modelling (SEM) to obtain a good fit of the full-fledged structural model.

\section{Conclusion}

In conclusion, given the growing importance of teleworking in the lives and operations of businesses, this research will allow practitioners to re-examine the concept of organisational borders and the nature of labour. The empowering of telework practices among labour union members necessitates a rethinking of organisational boundaries and a rethinking of physical and virtual boundaries. Furthermore, the results on various kinds of crisis may have once again to be generalised prudently as crises all have distinct health, social and economic effects. They tend to be distinctive and have special characteristics. In addition, crises such as health pandemic, as the physical and technological infrastructures of the organisation are left intact, vary from other crisis types. Meanwhile in the event of a natural catastrophe or conflict, the question of guaranteeing company continuity through teleworking is only closely connected to the phenomena studied in this very study.

\section{Acknowledgment}

The authors thank Universiti Malaysia Sabah (UMS) for valuable help in the research and publication process. This article is part of an ongoing doctoral study in the industrial relations field.

\section{Corresponding Author}

Name: Azizan H Morshidi

Affiliation: Faculty of Social Sciences \& Humanities, Universiti Malaysia Sabah.

Address: Universiti Malaysia Sabah, JIn UMS, 88400 Kota Kinabalu, Sabah, Malaysia.

Email: azizanm@ums.edu.my

\section{References}

Abed, S. S. (2021). A literature review exploring the role of technology in business survival during the Covid-19 lockdowns. International Journal of Organizational Analysis.

Agba, M. S., Agba, A. O., \& Chukwurah, D. C. J. (2021). COVID-19 Pandemic and Workplace Adjustments/Decentralization: A Focus on Teleworking in the New Normal. BRAIN. Broad Research in Artificial Intelligence and Neuroscience, 11(4), 185-200.

Agba, A. O., Ocheni, S. I., \& Agba, M. S. (2020). COVID-19 and the World of Work Dynamics: A Critical Review. Journal of Educational and Social Research, 10(5), 119-119.

Allen, T. D., Regina, J., \& Waiwood, A. M. (2021). A worker-centric view of COVID-19. Industrial and Organizational Psychology, 14(1-2), 254-259. 
Azizan, M., Kee, Y. S., \& Ideris, M. B. (2021). Trade Union and Job Changes in Volatile Times: A Systematic Literature Review \& Future Research Agenda. International Journal of Academic Research in Business and Social Sciences, 11 (2), 923-937.

Benavides, F. G., Amable, M., Cornelio, C., Vives, A., Milián, L. C., Barraza, D., \& Delclos, J. (2021). The future of work after the COVID-19, the uncertain role of teleworking at home. Revista Brasileira de Saúde Ocupacional, 46.

Beauregard, T. A., Basile, K. A., \& Canónico, E. (2019). Telework: Outcomes and facilitators for employees. In R. N. Landers (Ed.), The Cambridge Handbook of Technology and Employee behavior (pp. 511-543). Cambridge: Cambridge University Press.

Belzunegui-Eraso, A., \& Erro-Garcés, A. (2020). Teleworking in the Context of the Covid-19 Crisis. Sustainability, 12(9), 3662.

Bérastégui, P. (2021). Teleworking in the aftermath of the Covid-19 pandemic: enabling conditions for a successful transition. ETUI Research Paper-Policy Brief.

Berg, P., Kossek, E. E., Misra, K., \& Belman, D. (2014). Work-life flexibility policies: Do unions affect employee access and use?. ILR Review, 67(1), 111-137.

Bilotta, I., Cheng, S. K., Ng, L. C., Corrington, A. R., Watson, I., Paoletti, J., ... \& King, E. B. (2021). Remote communication amid the coronavirus pandemic: Optimizing interpersonal dynamics and team performance. Industrial and Organizational Psychology, 14(1-2), 3640.

Biron, M., Peretz, H., \& Turgeman-Lupo, K. (2020). Trait Optimism and Work from Home Adjustment in the COVID-19 Pandemic: Considering the Mediating Role of Situational Optimism and the Moderating Role of Cultural Optimism. Sustainability, 12(22), 9773.

Buomprisco, G., Ricci, S., Perri, R., \& De Sio, S. (2021). Health and Telework: New Challenges after COVID-19 Pandemic. European Journal of Environment and Public Health, 5(2), em0073.

Caranto, M. M., Sergio, R. P., \& Oribiana, M. Z. (2020). Telecommuting Versus Traditional Work Environment: Determinants of Job Satisfaction as Perceived by Individual Contributors and Supervisors. In Eurasian Business Perspectives (pp. 35-46). Springer, Cham.

Carillo, K., Cachat-Rosset, G., Marsan, J., Saba, T., \& Klarsfeld, A. (2020). Adjusting to epidemicinduced telework: empirical insights from teleworkers in France. European Journal of Information Systems, 1-20.

Chang, Y., Chien, C., \& Shen, L. F. (2021). Telecommuting during the coronavirus pandemic: Future time orientation as a mediator between proactive coping and perceived work productivity in two cultural samples. Personality and individual differences, 171, 110508.

Cheng, C., Wang, H. Y., \& Ebrahimi, O. V. (2021). Adjustment to a "New Normal:" Coping Flexibility and Mental Health Issues During the COVID-19 Pandemic. Frontiers in Psychiatry, 12, 353.

Chudinovskikh, M. A. R. I. N. A., \& Tonkikh, N. A. T. A. L. I. A. (2020). Telework in BRICS: Legal, Gender and Cultural Aspects. BRICS Law Journal, 7(4), 45-66.

Crooks, C. L., Hogg, J. L., Martin, S. M., Grant, J., Lemoie, K., \& Robbins, M. (2020, July). Understanding Generational Factors in the Workplace: Current Considerations for Telework Practices and the Digital Native. In 2020 IEEE International Professional Communication Conference (ProComm) (pp. 168-172). IEEE. 
Dalton, D. W., Garrett, J., L Harp, N., \& McPhee, G. P. (2021). Antecedents and Consequences of Organizational Support for Alternative Work Arrangements in the Accounting Profession. Available at SSRN 3835893.

Dawis, R. V., \& Lofquist, L. H. (1984). A psychological theory of work adjustment: An individualdifferences model and its applications. University of Minnesota Press.

Dawis, R. V., England, G., \& Lofquist, L. (2000). Work adjustment theory. Encyclopedia of Psychology, 8, pp.268-269.

Fana, M., Milasi, S., Napierala, J., Fernandez-Macias, E., \& Vázquez, I. G. (2020). Telework, work organisation and job quality during the COVID-19 crisis: a qualitative study (No. 2020/11). JRC Working Papers Series on Labour, Education and Technology.

Furåker, B., \& Larsson, B. (2020). Trade union cooperation in Europe: patterns, conditions, issues (p. 157). Springer Nature.

Golden, T. D., Veiga, J. F., \& Dino, R. N. (2008). The impact of professional isolation on teleworker job performance and turnover intentions: Does time spent teleworking, interacting face-to-face, or having access to communication-enhancing technology matter? Journal of Applied Psychology, 93(6), 1412-1421.

Khan, M. S., \& Umer, H. (2021). Benefits and Challenges of COVID-19 Induced Telework Across Gender: Policy Lessons for Sustainable Future Telework. Available at SSRN 3848640.

Kim, T., Mullins, L. B., \& Yoon, T. (2021). Supervision of Telework: A Key to Organizational Performance. The American Review of Public Administration, 51(4), 263-277.

Lashani, E., \& Zacher, H. (2021). Do we have a match? Assessing the role of community in coworking spaces based on a person-environment fit framework. Frontiers in Psychology, 12, 225.

Lott, Y., \& Abendroth, A. K. (2020). The non-use of telework in an ideal worker culture: why women perceive more cultural barriers. Community, Work \& Family, 23(5), 593-611.

Ma, G., Hen, K. W., \& Chooi, T. F. (2019). Telecommuting Adaptation in Malaysia: Demographics, Beliefs and Practices. Asian Social Science and Humanities Research Journal (ASHREJ), 1(1), 11-18.

Namgoong, J. (2020). The Republic of Korea's Policy Response to the Covid-19 epidemic in the field of employment and labour relations. Noticias CIELO, 12.

Raghuram, S., Hill, N. S., Gibbs, J. L., \& Maruping, L. M. (2019). Virtual work: Bridging research clusters. Academy of Management Annals, 13(1), 308-341.

Raghuram, S., Garud, R., Wiesenfeld, B., \& Gupta, V. (2001). Factors contributing to virtual work adjustment. Journal of Management, 27(3), 383-405.

Rodinova, N., Ostroukhov, V., Vasyukov, V., Goncharov, V. V., \& Novikov, A. V. (2021). Telework: restrictions' impact on the development of modern legal regulation of labour relations. Laplage em Revista, 7(Extra-B), 406-413.

Thomas, A., Boyle, E., Butler, W., Decker, G., \& Peters, J. (2020). Organizational Politics and Teleworkers: A Case Study. In The Tenth International Conference on Engaged Management Scholarship.

Shcherbakova, O., \& Smolina, J. (2021). The Peculiarities of Legal Regulation of Labor Discipline for Remote Workers. In VIII International Scientific and Practical Conference'Current problems of social and labour relations'(ISPC-CPSLR 2020) (pp. 615619). Atlantis Press.

Sischka, P., \& Steffgen, G. (2021). Extended telecommuting due to COVID-19 and the impact on working life. Self and Society in the Corona Crisis. Perspectives from the Humanities and Social Sciences. 
Sládek, P., \& Sigmund, T. (2021). Legal Issues of Teleworking. In SHS Web of Conferences (Vol. 90, p. 01020). EDP Sciences.

Wang, B., Liu, Y., \& Parker, S. K. (2020). How does the use of information communication technology affect individuals? A work design perspective. Academy of Management Annals, 14(2), 695-725.

Zhang, S., Moeckel, R., Moreno, A. T., Shuai, B., \& Gao, J. (2020). A work-life conflict perspective on telework. Transportation Research Part A: Policy and Practice, 141, 5168. 